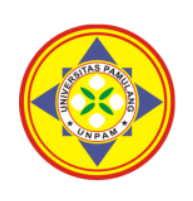

\title{
ANALISIS TINGKAT KESEHATAN BANK DENGAN MENGGUNAKAN METODE RGEC PADA PT BANK NEGARA INDONESIA (PERSERO)
}

\author{
${ }^{1 *}$ Ihwan Satria Lesmana, 2 Ika Fahyanti \\ Universitas Bina Bangsa, Banten, Indonesia \\ *ihwansatrialesmana@gmail.com
}

\begin{abstract}
Abstrak
Pesatnya perkembangan perusahaan perbankan di Indonesia ditandai dengan banyaknya perusahaan perbankan yang bermunculan, diperlukan pengawasan pada perusahaan perbankan. Dalam hal ini Bank Indonesia sebagai bank sentral memerlukan suatu kontrol terhadap perusahaan perbankan untuk mengetahui keadaan keuangan serta kegiatan usaha masing-masing perusahaan perbankan. Jenis penelitian ini tergolong dalam penelitian kualitatif. Sumber data dalam penelitian ini adalah data sekunder. Data yang diperoleh dari PT. Bank Negara Indonesia (persero) Tbk diuji melalui analisis rasio keuangan dan analisis kesehatan bank. Hasil penelitian tingkat kesehatan bank pada PT. Bank Negara Indonesia (persero) Tbk periode 2016-2020 dapat dilihat dari komponen faktor Risk Profile menggunakan rasio keuangan Non Performing Loan dikategorikan dalam predikat sangat sehat dan Loan to Deposite Ratio dikategorikan dalam predikat cukup sehat, dilihat dari komponen faktor Good Corporate Governance dikategorikan dalam predikat sehat, dilihat dari komponen faktor Earning menggunakan rasio keuangan Return On Assets dan Net Interest Margin dikategorikan dalam predikat sangat sehat, dilihat dari komponen faktor Capital menggunakan rasio keuangan Capital Adequacy Ratio dikategorikan dalam predikat sangat sehat.
\end{abstract}

Kata Kunci: Tingkat Kesehatan Bank, Metode RGEC

Abstract

The rapid development of banking companies in Indonesia is marked by the number of banking companies that have sprung up, requiring supervision of banking companies. In this case, Bank Indonesia as the central bank requires a control over banking companies to determine the financial condition and business activities of each banking company. This type of research is classified as qualitative research. The source of data in this study is secondary data. Data obtained from PT. Bank Negara Indonesia (Persero) Tbk was tested through financial ratio analysis and bank health analysis. The results of the research on the health of banks at PT. Bank Negara Indonesia (Persero) Tbk period 2016-2020 can be seen from the components of the Risk Profile factor using financial ratios. Non-Performing Loan is categorized as very healthy and the Loan to Deposit Ratio is categorized as quite healthy. healthy, seen from the components of the Earning factor using the financial ratios Return On Assets and Net Interest Margin categorized in the very healthy predicate, judging from the Capital factor component using the Capital Adequacy Ratio financial ratios categorized in the very healthy predicate.

Keywords: Bank Health Level, RGEC Method

\section{PENDAHULUAN}

Peristiwa krisis moneter yang melanda Indonesia pada pertengahan tahun 1997 dapat dijadikan sebagai suatu pelajaran untuk industri perbankan, krisis diawali dengan kesulitan likuiditas akibat merosotnya nilai tukar rupiah terhadap dollar AS. Krisis tersebut menyebabkan pencabutan usaha 16 bank swasta dan pengambil alihan kepengurusan bank karena besarnya BLBI sudah melebihi $200 \%$ oleh
Menteri Keuangan. Krisis perbankan kembali terjadi di Indonesia pada tahun 2008, krisis berdampak sistemik terhadap sektor perbankan, sehingga tingkat bunga diturunkan untuk meningkatkan konsumsi dan investasi. Berulangnya krisis perbankan tersebut terjadi karena bank merupakan institusi kepercayaan yang rentan terhadap penarikan dana besar-besaran oleh nasabah. Dimulai dari krisis moneter yang menghantam pada tahun 1997-1998, hingga 
yang saat ini masih terjadi, yaitu akibat Corona Virus Disease 2019 (COVID-19). Berikut perjalanan BNI dalam menapaki bermacam krisis yang pernah melandanya. Anjloknya nilai tukar rupiah ini memukul perekonomian, di mana saat itu perusahaan swasta kesulitan membayar kewajiban jangka pendek. Imbasnya adalah arus PHK yang tak bisa dibendung dan berujung pada problem sosial. Selanjutnya, rasio kredit bermasalah atau Non Performing Loan (NPL) mau tak mau juga terpengaruh, di mana posisi pada tahun 1998, NPL perbankan mencapai 48,6\%. Artinya, hampir dari setengah kredit yang disalurkan perbankan bermasalah. Masyarakat dihantui ketakutan, lantaran bank tempat mereka menyimpan uang kesulitan likuiditas. Kondisi ini menimbulkan bank rush alias masyarakat berbondong-bondong menarik dananya. Sama halnya dengan perbankan lain, BNI juga tak bisa menghindar dari hantaman badai krisis ini. Hal ini tercermin dari menurunya indikator kinerja finansial, bahkan keadaan ini menjadi periode paling kelam dalam sejarah BNI. Pertama adalah krisis yang terjadi pada tahun 1997-1998 di kawasan Asia, salah satunya Indonesia. Akibat krisis ini, rupiah tertekan dan mengalami penurunan terparah dalam jangka waktu lama. Bahkan rupiah sempat berada di level Rp 16.800/US\$. Padahal kala itu tepatnya pada akhir 1997 posisi rupiah masih di kisaran Rp 4.000 /US\$. Meski begitu, BNI menjadi salah satu bank BUMN pertama yang melantai di pasar modal, resmi mencatatkan sahamnya di Bursa Efek Jakarta dan Bursa Efek Surabaya pada 1996. Beruntung, kondisi tersebut tak berlarutlarut karena setelah krisis mencapai bottom, kinerja BNI pun berangsur membaik. Pada 1999 BNI memperkuat struktur keuangan dan daya saingnya di tengah industri perbankan nasional. BNI pun melakukan sejumlah aksi korporasi, antara lain proses rekapitalisasi oleh Pemerintah. Pada 2001 Bank BNI pun berhasil mengurangi jumlah NPL menjadi $19,54 \%$ dari total pinjaman atau senilai Rp 6,91 triliun. Kondisi ini jauh lebih rendah dibandingkan posisi tahun 2000 yang mencapai $\operatorname{Rp~7,96~triliun~atau~24,90\% ~dari~}$ total pinjaman. Kemudian, lagi-lagi krisis melanda pada tahun 2005. Kali ini penyebabnya cukup kompleks, yaitu harga minyak dunia dan meningkatnya nilai tukar dolar karena naiknya suku bunga acuan The Federal Reserve (The Fed). Berbekal krisis sebelumnya, yaitu pada tahun 1997-1998, BNI kali ini lebih waspada. BNI mencatat laba bersih $\operatorname{Rp} 1,42$ triliun dengan pendapatan bunga bersih Rp 6,9 triliun. Bahkan, likuiditas BNI juga tergolong sangat longgar di mana kala itu Loan Deposit Ratio (LDR) tercatat sebesar 52,4\%. ROA juga tercatat stabil di level 1,61\% dan ROE berada di level 12,64\%. Adapun NIM dan CAR masing-masing berada di posisi $5,35 \%$ dan $16 \%$.

Krisis berikutnya yang terjadi 12 tahun yang lalu tepatnya pada tahun 2008. Pasca 2005 sebenarnya ada masalah tersembunyi bagi finansial global, yakni kenaikan The Fed Funds Rate. Kenaikan bunga acuan ini menyebabkan pasar properti di Amerika Serikat runtuh. Saat itu, sebanyak 3,9 juta rumah di Amerika Serikat (AS) tak laku dan pengajuan pembangunan rumah baru turun hingga 28\%. Harga rumah sebagaimana dilaporkan National Association of Realtors turun $1,7 \%$ atau yang terparah dalam 11 tahun. Kondisi ini berimbas ke bursa derivatif yakni Subprime Mortgage Loan (KPR kelas dua). Lehman Brothers, yang dibangun tiga bersaudara Henry, Mayer, dan Emanuel Lehman adalah salah satu yang menjual KPR tersebut, yang telah dikemas ulang menjadi efek baru, yakni instrumen derivatif. Awalnya, efek ini dibuat untuk menjadi alat lindung nilai (hedging) pasar properti, atau sama halnya dengan Exchange Traded Fund (ETF) yang mengumpulkan efek dari berbagai aset agar risiko satu atau beberapa aset yang berkinerja buruk di dalamnya tertutupi oleh aset lain yang berkinerja baik. Namun sayangnya, saat semua aset tersebut ambruk, Lehman pun kesulitan. Akhirnya, Lehman angkat tangan dan dinyatakan pailit pada 15 September 2008.

Kepercayaan dan loyalitas nasabah terhadap bank merupakan faktor yang sangat membantu dan mempermudah pihak 
manajemen bank untuk menyusun strategi bisnis yang baik. Sebaliknya, para nasabah yang kurang kepercayaan kepada bank yang bersangkutan, maka loyalitasnya pun juga sangat tipis, hal ini tentu sangat tidak menguntungkan bagi bank yang bersangkutan karena para pemilik dana atau nasabah ini sewaktu-waktu dapat menarik dananya dan memindahkannya ke bank lain. Oleh karena itu, bank dituntut untuk bisa mencapai dan mempertahankan tingkat kinerja yang baik dan optimal, karena tingkat kinerja bank yang baik dapat meningkatkan kepercayaan dan loyalitas nasabah maupun masyarakat luas untuk menggunakan produk, jasa dan aktivitas keuangan dari bank tersebut.

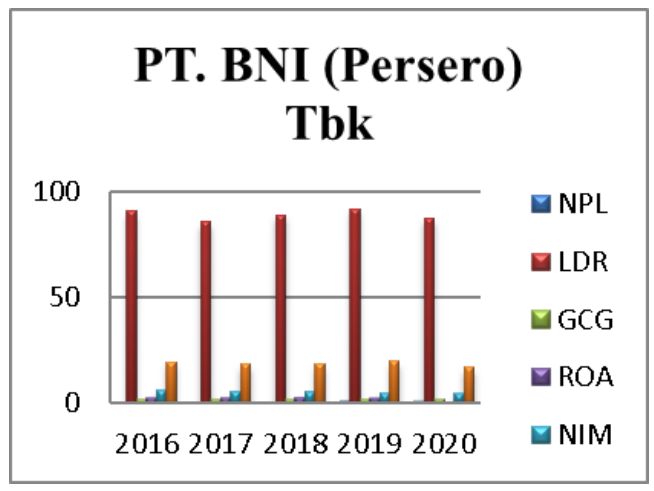

Sumber: Data diolah peneliti (www.bni.co.id)

Berdasarkan laporan keuangan yang diunduh melalui www.bni.co.id terdapat penurunan laba bersih pada PT. Bank Negara Indonesia (persero) Tbk tahun 2020 dibandingkan tahun sebelumnya. Pada tahun 2020 laba bersih sebesar Rp. 3,3 Triliun mengalami penurunan sebesar 78,6\% dibandingkan tahun 2019 yang sebesar Rp. 15,5 Triliun. Penurunan tersebut terjadi akibat tekanan masa pandemi covid-19 dan pendapatan bunga yang menurun. Penurunan NIM yang terjadi pada bank tersebut juga mengakibatkan kurang stabilnya aspek NIM, sehingga dapat mempengaruhi kesehatan bank. Nilai GCG yang cenderung stabil berarti belum adanya peningkatan yang signifikan pada bank tersebut

\section{METODE}

Metode penelitian adalah cara ilmiah mendapatkan data dengan tujuan dan kegunaan tertentu. Penelitian mengamati aspek-aspek yang berkaitan erat dengan masalah yang diteliti secara lebih pesifik, sehingga diperoleh data yang menunjukkan penyusunan laporan penelitian untuk diproses dan dianalisis berdasarkan teori yang telah dipelajari, sehingga diperoleh gambaran mengenai objek dan tarik kesimpulan mengenai masalah yang diteliti. Dalam penelitian ini digunakan jenis penelitian kualitatif dengan pendekatan deskriptif. Menurut Sugiyono metode penelitian kualitatif adalah metode penelitian yang berlandaskan pada filsafat postpositivism, digunakan untuk meneliti pada kondisi objek yang ilmiah, (sebagai lawannya adalah eksperimen) di mana penelitian adalah instrumen kunci, teknik pengumpulan data dilakukan secara triangulasi (gabungan), analisis data bersifat induktif atau kualitatif dan hasil penelitian kualitatif lebih menekan makna daripada generalisasi. Tempat Penelitian ini dilaksanakan pada perusahaan perbankan yaitu PT. Bank Negara Indonesia (persero) Tbk. Sumber data penelitian ini diperoleh dari laporan keuangan atau ikhtisar keuangan pada PT. Bank Negara Indonesia (persero) Tbk dengan mengakses web resmi perusahaan, yaitu www.bni.co.id.

\section{HASIL DAN PEMBAHASAN}

\section{Risk Profile ( Risiko Profil)}

Penilaian faktor profil risiko merupakan penilaian terhadap risiko inheren dan kualitas penetapan manajemen risiko dalam aktivitas operasional bank. Pada penelitian ini, yang akan dinilai menggunakan rasio keuangan hanya risiko kredit dan risiko likiuditas.

a. Risiko Kredit

Risiko kredit diukur dengan rasio Non Performing Loan (NPL). NPL (Non Performing Loan) merupakan perbandingan antara kredit yang bermasalah dengan total kredit. Rasio ini menunjukkan kemampuan manajemen bank dalam mengelola kredit bermasalah dalam bank. Rasio 
NPL diperoleh dari kredit bermasalah, yaitu merupakan kredit kepada pihak ketiga bukan bank yang tergolong kurang lancar, diragukan dan macet dibagi dengan total kredit kepada pihak ketiga bukan bank. Berikut hasil perhitungan rasio NPL PT. Bank Negara Indonesia (persero) Tbk periode 2016-2020.

$\begin{array}{ccccc}\text { Tahun } & \begin{array}{c}\text { Jumlah } \\ \text { Kredit } \\ \text { Bermasalah }\end{array} & \text { Total Kredit } & \text { NPL } & \begin{array}{c}\text { Kategori } \\ \text { Kesehatan }\end{array} \\ 2016 & 372.621 .478 & 974.783 .781 & 0,4 \% & \text { Sangat Sehat } \\ 2017 & 417.151 .310 & 547.716 .848 & 0,7 \% & \text { Sangat Sehat } \\ 2018 & 483.421 .821 & 584.392 .300 & 0,8 \% & \text { Sangat Sehat } \\ 2019 & 522.750 .099 & 522.750 .088 & 1,2 \% & \text { Sangat Sehat } \\ 2020 & 501.786 .774 & 548.613 .540 & 0,9 \% & \text { Sangat Sehat }\end{array}$

b. Risiko Likuiditas

Risiko Likuiditas diukur dengan rasio Loan to Deposite Ratio (LDR). Sebuah bank dikatakan likuid apabila bank yang bersangkutan dapat membayar hutang-hutangnya. LDR merupakan rasio likuiditas yang digunakan untuk mengukur kemampuan perusahaan dalam memenuhi kewajiban jangka pendek yang akan segera jatuh tempo pada saat ditagih secara keseluruhan.

Rasio LDR merupakan perbandingan antara total kredit dengan dana pihak ketiga bukan bank yang terdiri dari tabungan, giro dan deposito berjangka. Rasio LDR digunakan untuk mengukur perbandingan jumlah kredit yang diberikan bank dengan dana yang diterima oleh bank, yang menggambarkan kemampuan bank dalam membayar kembali penarikan dana oleh masyarakat dengan mengandalkan kredit yang diberikan sebagai sumber likuiditasnya. Berikut hasil perhitungan rasio LDR PT. Bank Negara Indonesia (persero) Tbk periode 2016-2020.

$\begin{array}{ccccc}\text { Tahun } & \begin{array}{c}\text { Jumlah } \\ \text { Kredit } \\ \text { Bermasalah }\end{array} & \begin{array}{c}\text { Dana } \\ \text { Pihak } \\ \text { Ketiga }\end{array} & \text { LDR } & \begin{array}{c}\text { Kategori } \\ \text { Kesehatan }\end{array} \\ 2016 & 372.621 .478 & 412.148 .167 & 90,4 \% & \text { Cukup Sehat } \\ 2017 & 417.151 .310 & 487.461 .507 & 85,6 \% & \text { Cukup Sehat } \\ 2018 & 483.421 .821 & 544.659 .543 & 88,8 \% & \text { Cukup Sehat } \\ 2019 & 522.750 .099 & 571.075 .697 & 91,5 \% & \text { Cukup Sehat } \\ 2020 & 501.786 .774 & 632.212 .284 & 87,3 \% & \text { Cukup Sehat }\end{array}$

\section{Good Corporate Governance (GCG)}

Penilaian faktor GCG merupakan penilaian terhadap kualitas manajemen bank atas pelaksanaan prinsip-prinsip GCG. Fokus penilaian terhadap pelaksanaan prinsip-prinsip GCG berpedoman pada ketentuan Bank Indonesia mengenai pelaksanaan GCG bagi bank umum dengan memperhatikan karakteristik dan kompleksitas usaha bank. Penilaian dilakukan dengan dilakukannya self assesment terhadap perusahaan perbankan tersebut. Dengan aspek governance structure, governance process, dan governance outcome. Nilai komposit GCG membantu peneliti dalam melihat keadaan GCG masing masing bank. Berikut merupakan tabel hasil peringkat penilaian komposit pada rasio GCG PT. Bank Negara Indonesia (persero) Tbk periode 2016-2020.

$\begin{array}{ccc}\text { Tahun } & \text { GCG } & \text { Kategori Kesehatan } \\ 2016 & 2 & \text { Sehat } \\ 2017 & 2 & \text { Sehat } \\ 2018 & 2 & \text { Sehat } \\ 2019 & 2 & \text { Sehat } \\ 2020 & 2 & \text { Sehat }\end{array}$

\section{Earning (Rentabilitas)}

Penilaian Earning/Rentabilitas pada analisis tingkat kesehatan bank menggunakan 2 rasio keuangan, yaitu ROA (Return On Assets) dan NIM (Net Interest Margin).

a. Return On Asset (ROA)

Merupakan rasio profitabilitas yang mampu menunjukkan keberhasilan suatu bank dalam menghasilkan keuntungan atau laba dengan mengoptimalkan aset yang dimiliki. ROA diperoleh dari laba sebelum pajak dibagi dengan rata-rata total aset. Rata-rata total aset dalam satu periode diperoleh dari menjumlahkan nilai aset awal periode dengan nilai aset akhir periode dan kemudian dibagi dua. Rasio ini dihitung untuk mengukur keberhasilan manajemen dalam menghasilkan laba. Semakin kecil rasio ini berarti manajemen bank 
kurang mampu dalam mengelola aset untuk meningkatkan pendapatan dan menekan biaya. Berikut hasil perhitungan rasio ROA PT. Bank Negara Indonesia (persero) Tbk periode 2016-2020.

$\begin{array}{ccccc}\text { Tahun } & \begin{array}{c}\text { Laba } \\ \text { Seb elum } \\ \text { Pajak }\end{array} & \begin{array}{c}\text { Rata-Rata } \\ \text { Total Asset }\end{array} & \text { ROA } & \begin{array}{c}\text { Kategori } \\ \text { Kesehatan }\end{array} \\ 2016 & 27.820 .239 & 1.167 .877 .231 & 2,7 \% & \text { Sangat Sehat } \\ 2017 & 33.492 .881 & 1.594 .494 .908 & 2,7 \% & \text { Sangat Sehat } \\ 2018 & 38.862 .641 & 1.563 .147 .221 & 2,8 \% & \text { Sangat Sehat } \\ 2019 & 37.629 .864 & 1.625 .842 .595 & 2,4 \% & \text { Sangat Sehat } \\ 2020 & 9.469 .801 & 1.709 .565 .096 & 0,5 \% & \text { Cukup Sehat }\end{array}$

b. Net Interest Margin (NIM)

Digunakan sebagai alat ukur untuk mengetahui tingkat rentabilitas bank yang diperoleh dari pendapatan bunga bersih atas aktiva-aktiva produktif atau aktiva yang menghasilkan bunga bersih. Rasio NIM diperoleh dari pendapatan bunga bersih dibagi rata-rata aset produktif. Pendapatan bunga bersih adalah pendapatan bunga setelah dikurangi dengan beban bunga. Aset produktif yang diperhitungkan adalah aset yang menghasilkan bunga. Rata-rata aset produktif dalam satu periode diperoleh dari menjumlahkan nilai aktiva produktif awal periode dengan nilai aset produktif akhir periode dan kemudian dibagi dua. Berikut hasil perhitungan rasio NIM PT. Bank Negara Indonesia (persero) Tbk periode 2016-2020.

\begin{tabular}{|c|c|c|c|c|}
\hline Tahun & $\begin{array}{l}\text { Pendapatan } \\
\text { Bunga } \\
\text { Bersih }\end{array}$ & $\begin{array}{c}\text { Rata-Rata } \\
\text { Asset } \\
\text { Produktif }\end{array}$ & NIM & $\begin{array}{c}\text { Kategori } \\
\text { Kesehatan }\end{array}$ \\
\hline 2016 & 2.999 .500 & 479.662 & $6,2 \%$ & Sangat Sehat \\
\hline 2017 & 3.193 .800 & 575.417 & $5,5 \%$ & Sangat Sehat \\
\hline 2018 & 3.544 .600 & 656.725 & $5,3 \%$ & Sangat Sehat \\
\hline 2019 & 3.660 .200 & 735.283 & $4,9 \%$ & Sangat Sehat \\
\hline 2020 & 3.715 .200 & 820.517 & $4,5 \%$ & Sangat Sehat \\
\hline
\end{tabular}

\section{Capital (Permodalan)}

$$
\text { Capital dapat diukur }
$$

menggunakan rasio keuangan Capital Adequacy Ratio (CAR). CAR atau sering disebut dengan istilah rasio kecukupan modal bank, yaitu bagaimana sebuah perbankan mampu membiayai aktivitas kegiatannya dengan kepemilikan modal yang dimilikinya. Rasio keuangan yang digunakan dalam menilai tingkat kesehatan bank umum BUMN ditinjau dari aspek capital pada penelitian ini adalah Capital Adequacy Ratio (CAR). Rasio CAR digunakan untuk mengukur kecukupan modal yang dimiliki bank untuk menunjang aktiva yang mengandung atau menghasilkan risiko. CAR merupakan rasio perbandingan antara modal dengan aset tertimbang menurut risiko. Risiko yang dimaksud di sini ada 3 risiko, yaitu Risiko Kredit, Risiko Operasional dan Risiko Pasar. Perhitungan modal dan Aset Tertimbang Menurut Risiko (ATMR) berpedoman pada ketentuan Bank Indonesia mengenai Kewajiban Penyediaan Modal Minimum Bank Umum (KPMM). Berikut hasil perhitungan rasio CAR PT. Bank Negara Indonesia (persero) Tbk periode 2016-2020.

\begin{tabular}{|c|c|c|c|c|}
\hline Tahun & Modal & $\begin{array}{c}\text { Aset } \\
\text { Tertimbang } \\
\text { Menurut } \\
\text { Resiko }\end{array}$ & CAR & $\begin{array}{c}\text { Kategori } \\
\text { Kesehatan }\end{array}$ \\
\hline 2016 & 84.278 .075 & 435.353 .579 & $16,8 \%$ & $\begin{array}{l}\text { Sangat } \\
\text { Sehat }\end{array}$ \\
\hline 2017 & 95.306 .890 & 514.476 .829 & $19,7 \%$ & $\begin{array}{l}\text { Sangat } \\
\text { Sehat }\end{array}$ \\
\hline 2018 & 104.254 .095 & 563.439 .969 & $18,5 \%$ & $\begin{array}{l}\text { Sangat } \\
\text { Sehat }\end{array}$ \\
\hline 2019 & 118.095 .752 & 598.483 .859 & $18,5 \%$ & $\begin{array}{l}\text { Sangat } \\
\text { Sehat }\end{array}$ \\
\hline 2020 & 103.145 .466 & 610.779 .907 & $19,4 \%$ & $\begin{array}{l}\text { Sangat } \\
\text { Sehat }\end{array}$ \\
\hline
\end{tabular}

Penilaian Peringkat Komposit Tingkat Kesehatan PT. BNI (Persero) Tbk

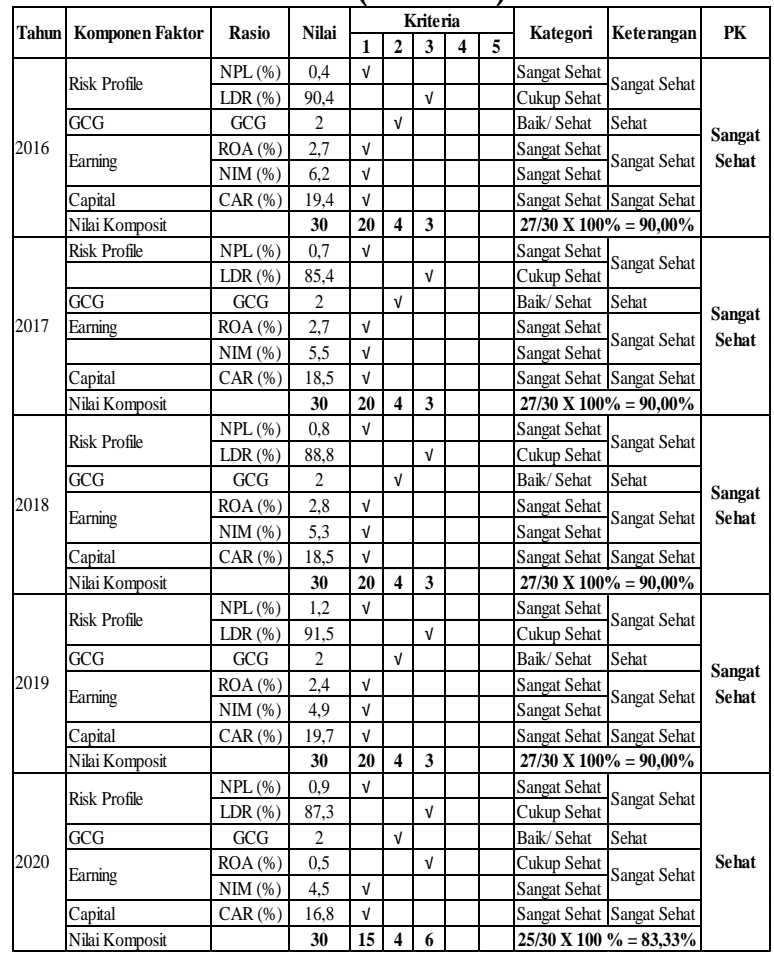

Sumber: Data Sekunder yang diolah peneliti

Hasil analisis tingkat kesehatan perusahaan perbankan tersebut 
berdasarkan metode RGEC selama tahun 2016-2019 menunjukkan bahwa kinerja bank berada pada peringkat komposit 1 (PK-1), yaitu terlihat dari nilai rasio keuangan yang meliputi Risk Profile, Good Corporate Governance, Earning, dan Capital secara keseluruhan berada dalam peringkat sangat sehat. Namun pada tahun 2020 kinerja bank berada pada peringkat komposit 2 (PK-2) dan dapat diartikan berada pada peringkat sehat menurut perhitungan metode RGEC. Ketika masa pandemi membuat keadaan ekonomi Indonesia yang menurun dibuktikan dengan penurunan pendapatan laba pada perusahaan perbankan tersebut. Namun hal itu bukanlah menjadi penghalang bagi PT. Bank Negara Indonesia (persero) Tbk untuk terus mempertahankan kinerja perusahan secara keseluruhan, sehingga tetap berada pada tingkat kesehatan bank yang sangat sehat.

\section{PENUTUP}

Berdasarkan hasil analisis yang telah dilakukan, maka dapat diambil kesimpulan, bahwa penilaian tingkat kesehatan bank pada PT. Bank Negara Indonesia (persero) Tbk berdasarkan perhitungan metode RGEC pada tahun 2016 sampai dengan 2020 jika diukur dengan komponen faktor Risk Profile menggunakan rasio keuangan Non Performing Loan (NPL) atau disebut juga Risiko Kredit secara keseluruhan berada pada posisi sangat sehat, jika diukur dengan komponen faktor Risk Profile menggunakan rasio keuangan Loan to Deposite Ratio (LDR) atau disebut juga Risiko Likuiditas secara kseluruhan berada pada posisi cukup sehat.

Penilaian Tingkat Kesehatan Bank pada PT. Bank Negara Indonesia (persero) Tbk berdasarkan perhitungan metode RGEC pada tahun 2016 sampai dengan 2020 jika diukur dengan komponen faktor Good Corporate Governance (GCG) berada pada posisi sehat dengan predikat baik dan mendapat nilai komposit 2 setiap tahunnya.

Penilaian Tingkat Kesehatan Bank pada PT. Bank Negara Indonesia (persero) Tbk berdasarkan perhitungan metode
RGEC pada tahun 2016 sampai dengan 2020 jika diukur dengan komponen faktor Earning dengan menggunakan rasio keuangan Return On Assets (ROA) secara keseluruhan berada pada posisi sangat sehat, jika diukur dengan komponen faktor Earning dengan menggunakan rasio keuangan Net Interest Margin (NIM) secara keseluruhan berada pada posisi sangat sehat.

Penilaian Tingkat Kesehatan Bank pada PT. Bank Negara Indonesia (persero) Tbk berdasarkan perhitungan metode RGEC pada tahun 2016 sampai dengan 2020 jika diukur dengan Komponen Faktor Capital dengan menggunakan rasio keuangan Capital Adequacy Ratio (CAR) secara keseluruhan berada pada posisi sangat sehat.

\section{DAFTAR PUSTAKA}

Agustina, Maulidiyah. 2015. Analisis Rasio Indikator Tingkat Kesehatan Bank Dengan Menggunakan Metode RGEC Pada PT. Bank Tabungan Negara Tbk. Jurnal Akuntansi AKUNESA vol. 3 no. 2.

Anik, dan Suhesti Ningsih. 2020. Analisis Tingkat Kesehatan Bank Mandiri Syariah dengan Metode Risk Profile, Good Corporate Governance, Earning, Capital. Jurnal Ilmiah Ekonomi Islam vol. 6 no.03.

Darwin, Juni. 2016. Analisa Tingkat Kesehatan PT. Bank Mandiri (persero) Tbk Dengan Metode RGEC. Jurnal Media Wahana Ekonomika vol.13 no.3.

Dianti, Edla. 2016. Analisis Tingkat Kesehatan Bank dengan Menggunakan Metode RGEC (Studi pada Bank Swasta yang Terdaftar di Bursa Efek Indonesia), Jurnal JOM FISIP vol. 3 no. 2 .

Erni, Ni Luh Gede. 2017. Manajemen Keuangan. Depok: Rajawali Pers.

Fahmi, Irham. 2017. Analisis Laporan Keuangan. Bandung: Alfabeta.

Ghozali, Zein. 2019, Analisis Tingkat Kesehatan Bank Dengan Menggunakan Metode RGEC (Studi Kasus Pada PT. 
Bank Muamalat Tbk) Periode 2012-2016. Jurnal MBIA no. 18 no.2.

Hafidhin, Ryan, dkk. 2018. Analisis Tingkat Kesehatan Bank Dengan Menggunakan Metode Risk Profile, Earning, Capital (Studi Pada PT. Bank Mandiri (persero) Tbk Periode 2013-2016. Jurnal Administrasi Bisnis vol.57 no.2.

Kasmir. 2015. Analisis Laporan Keuangan. Jakarta: Rajawali Pers.

Lestari, Dini Egi. 2021. Analisis Kesehatan Bank Menggunakan Metode RGEC. Jurnal Ilmu Manajemen vol. 4 no. 1.

Lutfi, A. M., et al. (2021). Pengaruh Capital Adequacy Ratio Dan Bopo Ratio Terhadap Return On Asset Pada Pt. Bank Muamalat Indonesia, Tbk Periode 2010-2019. Jurnal Ekonomi Efektif, 3(3), 420-428.

Ma'ruf, Dessy Oetari. 2019. Analisis Tingkat Kesehatan Bank Dengan Metode Risk Profile, Good Corporate Governance, Earning and Capital (RGEC) pada BPD Se-Indonesia Periode 2015-2017. Jurnal Emba, vol. 07 no.2.

Maramis, Pingkan Aprillia. 2019. Analisis Tingkat Kesehatan Bank Dengan Metode RGEC (Risk Profile, Good Corporate Governance, Earning, Capital) pada PT. Bank Mandiri (persero) Periode 20152018. Jurnal Pembangunan Ekonomi dan Keuangan Daerah vol. 20, no. 4.

Najibullah, N.,et al. (2021). Pengaruh non Performing Financing dan Financing to Deposit Ratio terhadap Pembiayaan pada Bank DKI Syariah. Jurnal Neraca Peradaban, 1(1), 48-55.

Pangaribuan, H., et al. (2021). The Financial Perspective Study on Tax Avoidance. Budapest International Research and Critics Institute (BIRCI-Journal): Humanities and Social Sciences, 4(3), 4998-5009.
Pramana, Komang Mahendra dan Luh Gede Sri Artini. 2016. Analisis Tingkat Kesehatan Bank (Pendekatan RGEC) Pada PT. Bank Danamon Indonesia Tbk. E-Jurnal Manajemen Unud vol. 5 no.6.

Putri, Putu Ainia Cahyani. 2017. Analisis Tingkat Kesehatan Bank Dengan Metode RGEC pada PT. Bank Tabungan Negara (persero) Tbk. E-Jurnal Manajemen Unud vol. 6 no. 7.

Rohmatika, Auliya dan Chairil Afandy. 2017. Analisis Tingkat Kesehatan Bank dengan Menggunakan Metode RGEC (Risk Profile, Good Corporate Governance, Earning, Capital) (Study pada PT. Bank Rakyat Indonesia (persero) Tbk periode 2013-2015). Jurnal Ilmiah Manajemen, vol. 12 no.1.

Shinta, Nur dan Indra Wijaya. 2016. Analisis Tingkat Kesehatan Keuangan Perbankan Menggunakan Metode RGEC (Studi Kasus Pada Bank BUMN Periode 20112014). Jurnal Mahsiswa Bina Insani vol. 1 no.1.

Sugiyono. 2012. Metode Penelitian Bisnis. Bandung: Alfabeta.

Sugiyono. 2014. Metode Penelitian Kuantitatif, Kualitatif dan RED. Bandung: Alfabeta.

Wahyudi, Heri. 2016. Analisis Tingkat Kesehatan Bank. Jurnal Bisnis Administrasi, vol.5 no.1.

Yunik, Zalfa. 2017, Analisis Kinerja Keuangan Menggunakan RGEC (Risk Profile, Good Corporate Governance, Earning, And Capital) Sebagai Metode Untuk Mengukur Tingkat Kesehatan Bank (Studi Pada Perusahaan Perbankan Yang Terdaftar di BEI Periode 2011-2016). Jurnal Administrasi Bisnis vol. 50 no. 6. 